BOVSH Ludmila,

$\mathrm{PhD}$ (Economics), Associate Professor, Associate Professor of the Department of Hotel and Restaurant Business Kyiv National University of Trade and Economics 19, Kyoto str., Kyiv, 02156, Ukraine

E-mail:l.bovsh@knute.edu.ua ORCID: 0000-0001-6044-3004
BOSOVSKA Myroslava,

DSc (Economics), Professor, Professor of the Department of Hotel and Restaurant Business Kyiv National University of Trade and Economics 19, Kyoto str., Kyiv, 02156, Ukraine

E-mail:m.bosovskaya@knute.edu.ua ORCID: 0000-0002-6021-5228

OKHRIMENKO Alla,

DSc (Economics), Associate Professor, Professor of the Department of Hotel and Restaurant Business Kyiv National University of Trade and Economics

19, Kyoto str., Kyiv, 02156, Ukraine

E-mail: a.okhrimenko@knute.edu.ua ORCID: 0000-0003-0405-3081

\title{
COMPLIANCE-STRATEGIZING OF ECONOMIC SECURITY OF THE BUSINESS IN DIGITALIZATION CONDITIONS*
}

The content, main tasks and functions of compliance-strategizing of economic security of business in the conditions of digitalization are revealed. Emphasis is placed on the need to consolidate and coordinate legal, economic, social and health aspects of security with compliance technologies and strategic planning of business processes, which will help ensure the competitiveness and risk protection of business, as well as on digital platforms. It is noted that it is necessary to separate resource potential as a part of corporate strategic compliance. An important area of further development of compliance-strategizing - "change management" - is considered.

Keywords: compliance, strategizing, economic security, compliance risks, economic security model, digitization, digital technologies, hospitality entity.

Background. The beginning of the XXI century marked by global challenges for the development of economic entities: financial crises, political conflicts, environmental catastrophes, the viral pandemic, which caused revolutionary changes in the public consciousness of business, reformatting their concepts and development strategies, intensified the need to respond to new threats to economic security and digitization of the socio-economic sphere.

The crisis has significantly affected the activities of the hotel and restaurant business, minimizing their opportunities and financial and economic potential. Therefore, hotels and restaurants need to actively adapt existing management mechanisms to the challenges and threats of economic security, the implementation of innovative, in particular, digital technologies for business security and its strengthening in the new economic realities. In this sense, the symbiosis of compliance technologies and strategic planning

* The article was prepared as part of the research work "Digital Transformation of Trade, Economic and Tourist Systems of Ukraine" (state registration number 0121U112231).

(C) Bovsh L., Bosovska M., Okhrimenko A., 2021 
of business processes will transform the processes of strategy, ensure their effectiveness and efficiency in terms of forming strategic prospects for business development and maintaining economic positions in the market. Therefore, the study of technologies and processes of compliance strategy in ensuring the economic security of hospitality is relevant. The process of compliancestrategizing requires theoretical and applied substantiation, development of methodological approaches to its implementation in the practice of hospitality entities (HE).

Analysis of recent research and publications. The issue of compliance-strategy of economic security of hospitality entities is determined by multifacetedness and covers the areas of compliance control, strategic planning and security technology in the context of total digitalization. Therefore, science and practice to determine the prospects for development require research of applied and analytical experience, scientific concepts and methods of their practical implementation on this range of issues. Thus, the experience of compliance as a concept of business reset in accordance with the requirements of the external environment is reflected in the scientific works of O. Vovk, A. Kovalchuk, P. Andrew [1]; as one of the effective methods of risk management - in the studies of V. Valiyev [2]; as an element of internal corporate governance - in N. Moskalenko's research [3], etc.

Regarding the theory and practice of strategizing, research covers mostly the institutional level and considers it as an additional link of power in addition to the legislative and executive function (T. Baker, D. Ceres, S. Spencer [4]; W. Bauer, W. Eremin [5]). The regional aspect of strategizing is revealed in the publications of A. Kasych, N. Kukharska, V. Chemerys [6-8]. Strategy as a competitive advantage of enterprises is the subject of V. Starbak's [9], S. Datsyuk's research [10].

At the same time, economic security as a complementary economic process is formed, detailed and contains debatable provisions in the focus of anti-crisis research, in particular in the scientific works of S. Dovbny, N. Gichova, E. Kalashnikov, S. Mityakova, E. Morozova, R. Nurey Rauf, O. Skiri, P. Tarlow, W. Zhu, W. San, K. Xiang [11-18]. Digitization as a determinant of the emergence of new risks and threats in the field of business management is the subject of research carried out by T. Coldwell, E. Savelieva, A. Kareva, V. Zeng, M. Kotni, S. Mukherjee, O. Oluvatimi, M. Damiani, E. Bertino [19-24]. At the same time, in the hotel sector, certain aspects of economic security have been revealed by such scientists as: L. Malyuk, L. Varypayeva, A. Sakhirova, I. Sosnovska, O. Yudina [26-29].

The results of the analysis of available scientific sources show that the issues of formation of the terminological basis of compliance-strategic economic security, substantive characteristics of its structural elements, the processes of economic security in the digital space of hospitality remain insufficiently explored. Addressing these issues requires a holistic approach that will transform existing economic security provisions with new economic challenges. 
These scientific studies confirm the importance and relevance of developing theoretical, methodological and applied principles of compliance-strategy of economic security of the HE on a systemic basis.

The aim of the article is to operationalize the content of economic security of hospitality entities and the formation of a conceptual model for the implementation of compliance strategy as a holistic multilevel poly-object mechanism in the context of digitalization.

Materials and methods. The study of the essence and economic security of HE, the peculiarities of the formation of its components is carried out using general scientific research methods: abstraction, concretization, systematization, decomposition, analytical, logical and generalizations. Methods of analysis and synthesis, forecasting, cognitive modeling are used to substantiate the theoretical aspects of the concept and construction of a complementary model of economic security of HE. The method of paired molecular docking was used to determine the architectonics of the benchmarks of economic security HRBE. The information base of the study was scientific works in the field of compliance, strategic management, economic security; online analytics and official statistical sources.

Results. The global crisis has caused economic, informational and epidemiological challenges for hospitality entities: reduced activity in consumer behavior in the market of hotel and restaurant services, limited financial opportunities and strategic potential of economic entities have become catalysts for finding new management technologies capable of reengineering and management audit of business processes, focus on strategic development and ensuring efficiency. An effective tool for the systematic management of the hospitality entity is compliance strategy as a set of actions that not only provides positive prospects for development, but also is able to generate management decisions aimed at overcoming strategic challenges and implementing global trends, including digital technologies.

To adequately understand the principles and functions of compliance strategy, we analyze the practical application of the key definition. Compliance-strategying in the semantic context comes from English from the terms "compliance" - agreement, compliance, compliance with rules, standards, laws and "strategizing" - a well-thought-out detailed plan for success [30]. Compliance in the legal practice of Ukraine is first defined in the Guidelines for improving corporate governance in Ukrainian banks as the need to know, understand and comply with all requirements of Ukrainian legislation, regulations, provisions and rules, internal policies, standards and codes of the bank [31]. In today's business environment, "compliance" is synonymous with good and efficient management and, according to the International Compliance Association, is the competence of the organization to act in accordance with established external and internal rules, standards, requirements and restrictions [32]. At the same time, the practice of compliance with economic entities allowed to identify it as a multi-aspect management activity that takes into account the following structural components: antitrust, anti-corruption, contractual, health and safety, digital security, 
personal data protection, insider and confidential information; fraud prevention; environmental, ethical, informational, corporate, tax, combating money laundering and legalization of income, regulatory, reputational, technical, conflict of interest avoidance, financial, etc. $[1 ; 26 ; 33]$. At the same time, the HE compliance system covers an autonomous set of these components in order to ensure compliance with legal norms, corporate documents and internal standards of management and operations.

Thus, compliance transforms the HE management system and determines from the standpoint the ability to provide: resilience in changing conditions (including in an unfavorable, uncertain and risky, capable of radical digital transformations economic environment); compliance with legal and corporate conditions and rules of doing business; opportunities to form mutually beneficial strategic relationships with micro- and macroentities, which is an important model designer of strategic behavior of HE.

In general, the component of compliance fits well into the functionality of economic security as a tool to ensure sustainable development, protection from adverse factors and conditions of the external and internal environment. The compliance function promotes the standardization of management decisions in accordance with established regulations, laws, rules, procedures, etc., which prevents financial and economic threats and sanctions from stakeholders and counterparties, including public authorities. In addition, active communication with staff and society orients the HE to ensure social responsibility - compliance with integrity, ethics, support of socio-economic infrastructure of the regions, environmental norms and rules. The system of compliance functions and processes is complemented by the quality of services and service as one of the targets of strategic management and an important criterion in the implementation of consumer choice. Thus, compliance formalizes a set of functions and processes in the HE management system (Figure 1).

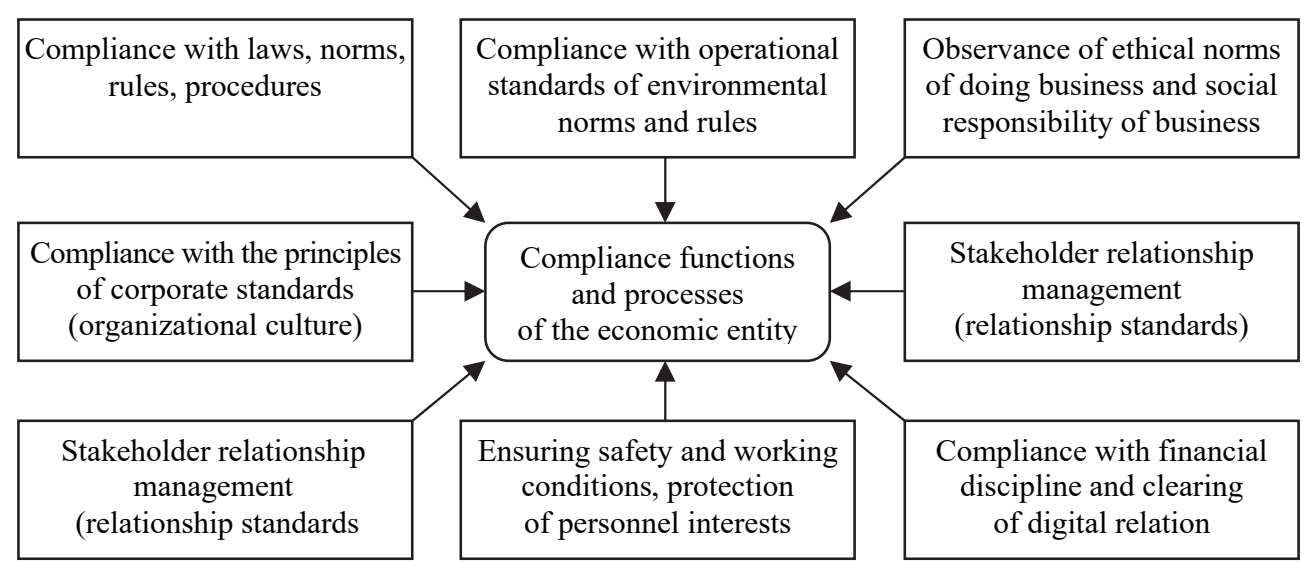

Figure 1. Functional and process structuring of compliance

Source: developed by the authors. 
Particular attention should be paid to clearing, which involves control over settlement transactions for hotel and restaurant and other services, goods and securities in accordance with bilateral obligations. At present, this term should be extended to digital relations, given its origin from English "Clearing - to clear, to bring clarity" [30]. In this case, we propose to treat the clearing of digital relations as business processes related to the monitoring and implementation of economic relations in distribution systems, customer-oriented technologies and electronic payments (including blockchain), as well as control over the qualitative completion of digital operations, systematic feedback of processes on digital platforms. The digital market includes not only websites and brand books, marketplaces (distributors and commercial and financial platforms), but also social networks, blogs, messenger channels (chatbots, telegram channels, YouTube streams, etc.), so it is necessary to adhere to quality and etiquette, financial discipline in maintaining relations, which affects the reputation of the hotel and restaurant business.

These functions and processes (Figure 1) cover behavioral attitudes and processes at the internal, micro and macro levels of the economic system and relations between actors, taking into account their characteristics, interests, needs and capabilities, which requires targeted management actions in developing goals and measures to achieve the goals of each of the participants - strategic planning (strategizing). Strategizing will ensure the economic security of the enterprise through the use of available resources and opportunities, the formation of the ability to navigate the market situation, diagnose their own economic potential, development prospects and strategic interests of the external environment.

In research on strategic management strategizing is presented as a systemic paradigm of the strategic management process, which includes strategic goal setting, forecasting, formation of alternative scenarios, design, programming, planning, communicative foresighting, situation analysis and consequences, strategy implementation and controlling [7]. On the other hand, it is a way of multidimensional (multifocal) self-management of development [10] based on constructive dialogue and cooperation with stakeholders [27], which creates a rational system to support strategic actions [9]. Thus, strategizing outlines strategic guidelines that are supported by economic resources and management competencies of development (monitoring, planning, accounting and auditing, communications management, controlling, etc.) of the business.

In Table scientific approaches to determining and ensuring compliance with strategy are summarized. 
Compatible and meaningful systematization of approaches to understanding of compliance strategy

\begin{tabular}{|c|c|c|c|}
\hline Approach & Content & $\begin{array}{l}\text { Methods and technologies } \\
\text { of implementation }\end{array}$ & Limitation \\
\hline $\begin{array}{l}\text { Ensuring } \\
\text { information } \\
\text { and financial } \\
\text { security }\end{array}$ & $\begin{array}{l}\text { Information protection } \\
\text { and prevention of fraud }\end{array}$ & $\begin{array}{l}\text { Construction of a two-level information } \\
\text { protection system: } \\
\text { - internal security of the enterprise; } \\
\text { - responsibility and vigilance of staff for } \\
\text { work in the market and with partners }\end{array}$ & $\begin{array}{l}\text { Does not cover the whole } \\
\text { set of external and internal } \\
\text { threats to the enterprise, } \\
\text { reactive control } \\
\text { mechanisms }\end{array}$ \\
\hline $\begin{array}{l}\text { Forecasting } \\
\text { and planning }\end{array}$ & $\begin{array}{l}\text { Protection of the } \\
\text { internal system and } \\
\text { creation of favorable } \\
\text { economic conditions }\end{array}$ & $\begin{array}{l}\text { Use of advanced management } \\
\text { and information technologies }\end{array}$ & $\begin{array}{l}\text { It is used if there } \\
\text { is a strategy, plan, resource } \\
\text { availability. }\end{array}$ \\
\hline Authoritative & $\begin{array}{l}\text { Providing systems } \\
\text { for the protection } \\
\text { of personnel, financial } \\
\text { and material resources, } \\
\text { information }\end{array}$ & $\begin{array}{l}\text { Business process management } \\
\text { of the enterprise }\end{array}$ & $\begin{array}{l}\text { Excessive administration } \\
\text { and documentation } \\
\text { of processes, low } \\
\text { adaptation to new external } \\
\text { challenges }\end{array}$ \\
\hline Financial & $\begin{array}{c}\text { Ensuring financial } \\
\text { security and stability }\end{array}$ & $\begin{array}{l}\text { Implementation of effective mechanisms } \\
\text { of enterprise financial security }\end{array}$ & $\begin{array}{l}\text { Narrow understanding } \\
\text { of compliance }\end{array}$ \\
\hline Adaptive & $\begin{array}{c}\text { The ability to respond } \\
\text { preventively to threats } \\
\text { or to adapt to changing } \\
\text { conditions }\end{array}$ & $\begin{array}{l}\text { Methods and means of situational } \\
\text { approach }\end{array}$ & $\begin{array}{c}\text { Reactive nature } \\
\text { of the response, } \\
\text { insufficient consideration } \\
\text { of internal factors }\end{array}$ \\
\hline $\begin{array}{l}\text { Resource- } \\
\text { functional }\end{array}$ & $\begin{array}{c}\text { Ensuring the } \\
\text { development of resource } \\
\text { and functional potential }\end{array}$ & $\begin{array}{l}\text { Methods and technologies of strategic } \\
\text { management, use of methodologies } \\
\text { of situational and resource approaches }\end{array}$ & $\begin{array}{l}\text { Complexity, high cost, } \\
\text { the need to develop } \\
\text { corporate standards }\end{array}$ \\
\hline Strategic & $\begin{array}{c}\text { Optimization } \\
\text { of the corporate } \\
\text { resources use, } \\
\text { competitive advantages } \\
\text { formation }\end{array}$ & $\begin{array}{l}\text { Research of indicators set of economic } \\
\text { activity on a complex of functional } \\
\text { components of activity }\end{array}$ & $\begin{array}{l}\text { Full and wide coverage } \\
\text { of processes, focus } \\
\text { on economic efficiency } \\
\text { (leveling of environmental } \\
\text { and social aspects) }\end{array}$ \\
\hline Authorial & $\begin{array}{l}\text { Focus on internal } \\
\text { opportunities use in the } \\
\text { external environment, } \\
\text { ensuring economic } \\
\text { security }\end{array}$ & $\begin{array}{l}\text { Monitoring changes in the external } \\
\text { environment, identifying economic } \\
\text { opportunities and benefits, the use of } \\
\text { digital and innovative technologies, } \\
\text { establishing strategic partnerships with } \\
\text { the environment; control of potential, } \\
\text { opportunities, risks, threats, costs, losses }\end{array}$ & $\begin{array}{l}\text { Management mechanisms } \\
\text { are focused on the internal } \\
\text { balancing of business } \\
\text { processes, resources, } \\
\text { interests and the formation } \\
\text { of competitive advantages }\end{array}$ \\
\hline
\end{tabular}

Source: developed by the authors according to [7-11;28; 33-35].

The generalization of these scientific approaches to the substantive understanding of compliance-strategizing makes it possible to identify its key characteristics, which should be taken as a basis for its contamination and the definition of the main portfolio of driver mechanisms:

- formation of vision, which is transformed into the development of strategic guidelines for the development of the HE;

- defining of formalized and restrictive rules, conditions and procedures, as well as the ability of the HE to form a "critical mass" of the necessary resource potential and ensure organizational competencies;

- effectometry of HE management and its financial capabilities;

- development of marketing potential, competitive advantages and digital opportunities;

- mentoring of the economic system as a process of mentoring and supervision of $\mathrm{HE}$ in order to identify problems and growth points that 
provide competency management and force the object (business, project, processes) to successful implementation [25];

- compliance control of potential, opportunities, risks, threats, costs, losses, etc.

Within compliance strategizing acquires a new conceptual content, which reveals new opportunities for relationship management based on digital technologies, compliance technologies and risk management. At the same time, the strategic component in the economic security management system creates conditions for the foresight of risks and threats, when the effectiveness of the HE management system is ensured, outposts are built to protect against financial and reputational losses and gain a competitive position.

Thus, compliance-strategizing is proposed to be considered as a policy for the formation and controlled implementation of strategic guidelines for the development of economic entities, which are determined by formal conditions, resource capabilities, operational procedures, external and internal constraints (legislation, regulations, socio-economic, environmental, legal and corporate culture).

In the outlined semantic plane, compliance-strategizing of economic security requires filling the content of the concept and strategy of development of the economic entity with components that will provide protection against external threats and internal risks - economic security. In general, comparative economics according to scientific sources $[11 ; 27 ; 28 ; 34]$ interprets it as a state of protection of the economic potential of the entity and the interests of its owners and stakeholders from possible dangers, threats and stresses, as well as ensures stable and sustainable operation and effective development in accordance with its strategic goals. To implement compliance strategy, we will decompose the SG economic security system by security objects (Figure 2).

\begin{tabular}{|c|c|c|c|c|}
\hline \multirow{3}{*}{ 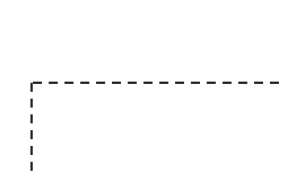 } & \multicolumn{3}{|c|}{ Production potential } & \multirow[b]{2}{*}{ ן } \\
\hline & Strategic sessions & \multicolumn{2}{|r|}{ Tactical tasks } & \\
\hline & Indicators & \multicolumn{2}{|r|}{ Compliance control } & \\
\hline \multicolumn{2}{|c|}{ Marketing potential } & $\mathbf{S}$ & \multicolumn{2}{|c|}{ Digital potential } \\
\hline Strategic sessions & Tactical tasks & \multirow{2}{*}{$\mathbf{T}$} & Strategic sessions & Tactical tasks \\
\hline Indicators & Compliance control & & Indicators & Compliance control \\
\hline$i$ & & & & $!$ \\
\hline \multicolumn{2}{|c|}{ Financial potential } & $\mathbf{T}$ & \multicolumn{2}{|c|}{ Human potential } \\
\hline Strategic sessions & Tactical tasks & \multirow{2}{*}{$\begin{array}{l}\mathbf{E} \\
\mathbf{G} \\
\mathbf{Y}\end{array}$} & Strategic sessions & Tactical tasks \\
\hline Indicators & Compliance control & & Indicators & Compliance control \\
\hline
\end{tabular}

Figure 2. Compliance-strategizing decomposition of the economic security system of the hospitality entity

Source: developed by the authors according to $[8 ; 33 ; 35]$. 
Within the framework of compliance-strategic economic security, the production and operational potential includes diagnostics of material and technical resources usage of HE from the standpoint of creating preconditions for strategic development: technical, technological and physical conditions for service provision, quality of service and facility facilitation. At the same time, tactical tasks include work on assessing the condition of facilities, operational characteristics, service delivery processes, usage of material and technical base, property and equipment, level of service quality and their compliance with regulatory and consumer requirements, and include effectometry of business processes and individual production operations.

Marketing and digital (analytical and informational) potential is formed at the area of non-material assets of the HE. The marketing potential will serve to the commercial sphere, wheree strategic decision are focused on the formation of positive reactions of consumers and partners to environmental challenges. It forms a sales system provided by distribution; marketing activities; relationship management, consumer behavior and impressions; creating a positive image and corporate brand.

In turn, digital (information-analytical) potential is associated with the accumulation of positive experience (partnerships, regular customers, analytical findings, customers and partners databases) and intellectual property. Strategic sessions in this perspective are aimed at information protection, implementation of digital technologies, development of information systems and ensuring a positive reputation of HE, its customer orientation. Tactical tasks determine management decisions to ensure the interests of management, owners and stakeholders.

Financial potential plays a key role, because the capabilities of all other potentials depend on its capacity. Strategic sessions focus on the formation and development of unique internal capital, developmental organizational competencies, effective human capital and investment usage. It was thanks to the financial reserves that most HE were able to overcome the global financial crises and the consequences of the coronavirus pandemic. Tactical tasks in this case are financial flows management, monitoring of threshold values of financial state indicators and reducing the likelihood of bankruptcy.

Human potential has become the central object of management attention, as its competence characteristics and devotion define competitiveness and prospects of the HE. Strategic sessions are focused on creating favorable working conditions, implementation of team work principles, progressive HR technologies, mentoring, corporate culture and motivation to productive work. At the same time, tactical tasks are focused on identifying stresses and professional burnout, preventing conflicts, low-quality processes and operations, and individualizing staff rewards.

Based on the key elements of economic potential, the policy of economic security can be represented as s a complementary model based on the concept of target coverage of the hospitality entities (Figure 3). 


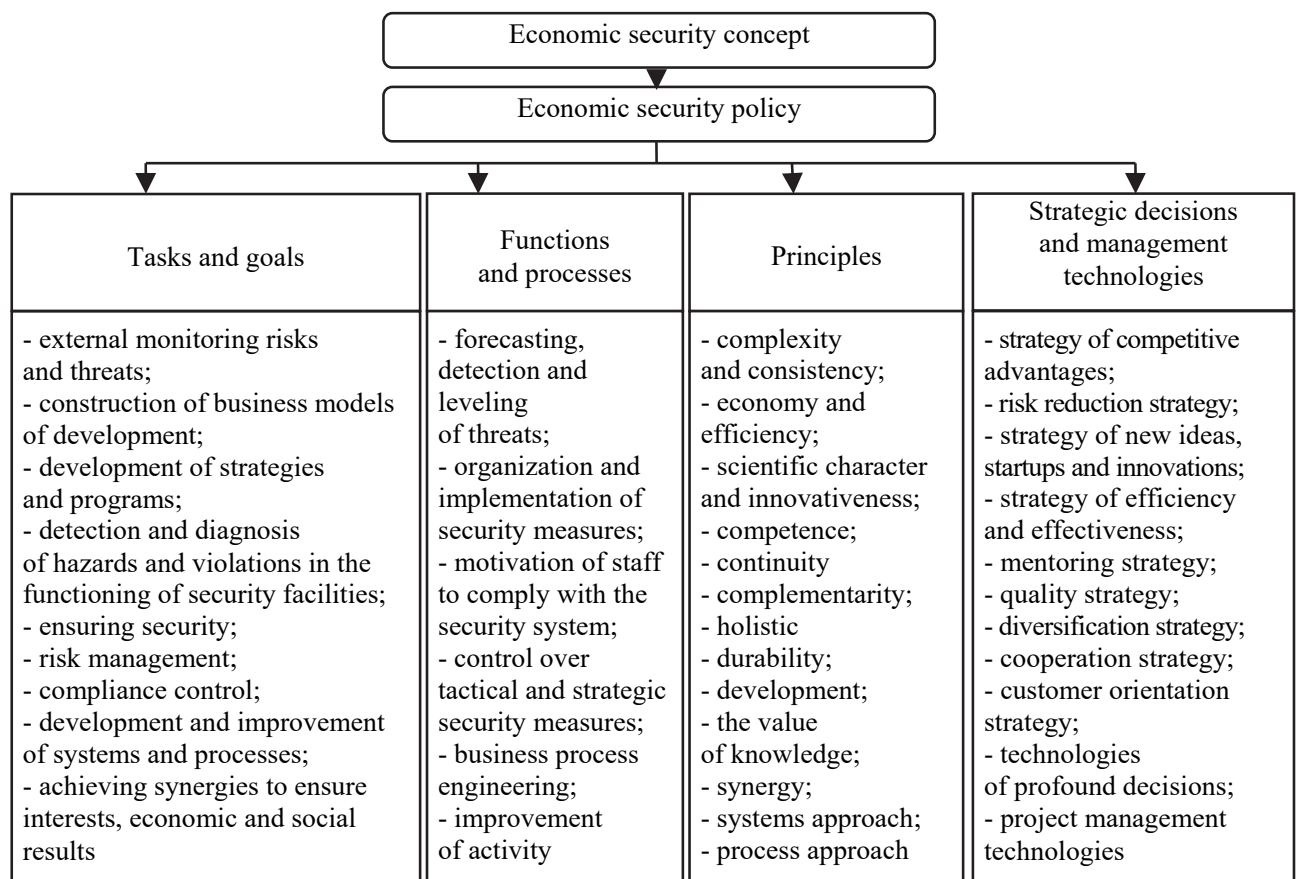

Figure 3. Complementary model of the economic security concept of the hospitality entity

Source: developed by the authors according $[8 ; 20 ; 33 ; 35 ; 36]$.

The main task is to anticipate and rehabilitate risks and possible threats that cause a crisis, as well as the implementation of anti-crisis actions based on the development and implementation of organizational, technical, economic, legal, environmental and social measures.

Thus, compliance strategizing will be aimed at diagnosing economic security according to the following parameters:

- assessment of threats and potentials of the external environment. The evaluation methodology contains the tools of strategic management and marketing, in particular: SWOT-analysis, PEST-analysis, SPACE-analysis, SNW-analysis, VMOST-analysis, etc. [37];

- analysis of the marketing environment and potential: diagnostics of the sales system, distribution and its separate channels; website, brand book, mobile applications, social pages and blogs; loyalty systems; customer orientation and competitiveness, etc., using a multi-vector resource-functional model of economic security, assessment of the competitive status of the firm, an integrated assessment of compliance with the company's interests [11;34];

- study of the internal environment and its potentials (probability of bankruptcy, financial condition and investment and innovation development, management quality, facilitation level and ajilization of business processes, quality of material and technical base and processes, information security and protection of intellectual property, HR-security, etc.) through indicators of efficiency, effectiveness, achievement of goals, business activity, probability of bankruptcy according to the Altman model, etc.; application 
of the three-dimensional diagnostics model of economic security [16], as well as the use of a balanced scorecard (BSC), a system of responsibility indicators (Associability Scorecard - ASC), a model of business advantage (Business Excellence Model - BEM);

- the effectiveness of security costs (return on investment, reputational costs, level of risk protection, impact on the overall financial condition, etc.).

Diagnostic compliance allows the management of economic security to rely on permissible safety criteria (standards of normality) - threshold values of indicators and achievement of the expectations of personnel and stakeholders, as well as the interests of owners and management.

Analytical studies of today's realities mark the external environment of Ukrainian HE as quite unstable. Thus, the results of surveys of service entities [36] processed in accordance with the Methodology for calculating indicators of business expectations [38] show radical negative changes in the business situation for development prospects in the second half of 2014 - first half of 2021 from the standpoint of these entities. In the study, with the maximum possible score of 100 points for Ukrainian hotel business entities, the highest risk assessment was in the first half of 2017 and the lowest in 2020; in general, the average score for the period is negative - "-5 points" (Figure 4).

Changes in the business situation for strategic development are negatively characterized by restaurant business entities.

Another area of surveys of service entities [31] demonstrates the dynamics of the change in demand for services (sales volume of services) (Figure 5).

In general, we note a fairly low level of expectations of hotel and restaurant business entities (HRBE) in Ukraine regarding the positive and rapid change of the business situation in the field of Horek and the growth of demand for services. Thus, the average expectation of changes in demand for hotel services in this period is 4 points, and in the restaurant business -16 points. Moreover, if in the hotel business in the middle of 2021 expectations about the development prospects have already gained positive trends: "+24 points", for the restaurant business still remain negative: "-24 points".

Deterministic indicators of expectations still remain at a relatively low level, therefore, the high relevance and the need to expand the mechanisms for ensuring the economic security of the HRBE are argued. Accordingly, at the macro-, mega- levels, it manifests itself through:

- development of hotel and restaurant product branding, destinations, tourist facilities and business;

- ensuring customer orientation of the hotel and restaurant business;

- their predominant functioning in the format of integrated structures of business networks with the consolidation of processes and resources;

- multifaceted cooperation and involvement of stakeholders in business processes (including partners, suppliers, consumers, etc.);

- establishing institutional support through the formation of public-private partnership projects, cooperation with local communities and public organizations;

- performance of social, ecological functions in regions and destinations by subjects, etc. 

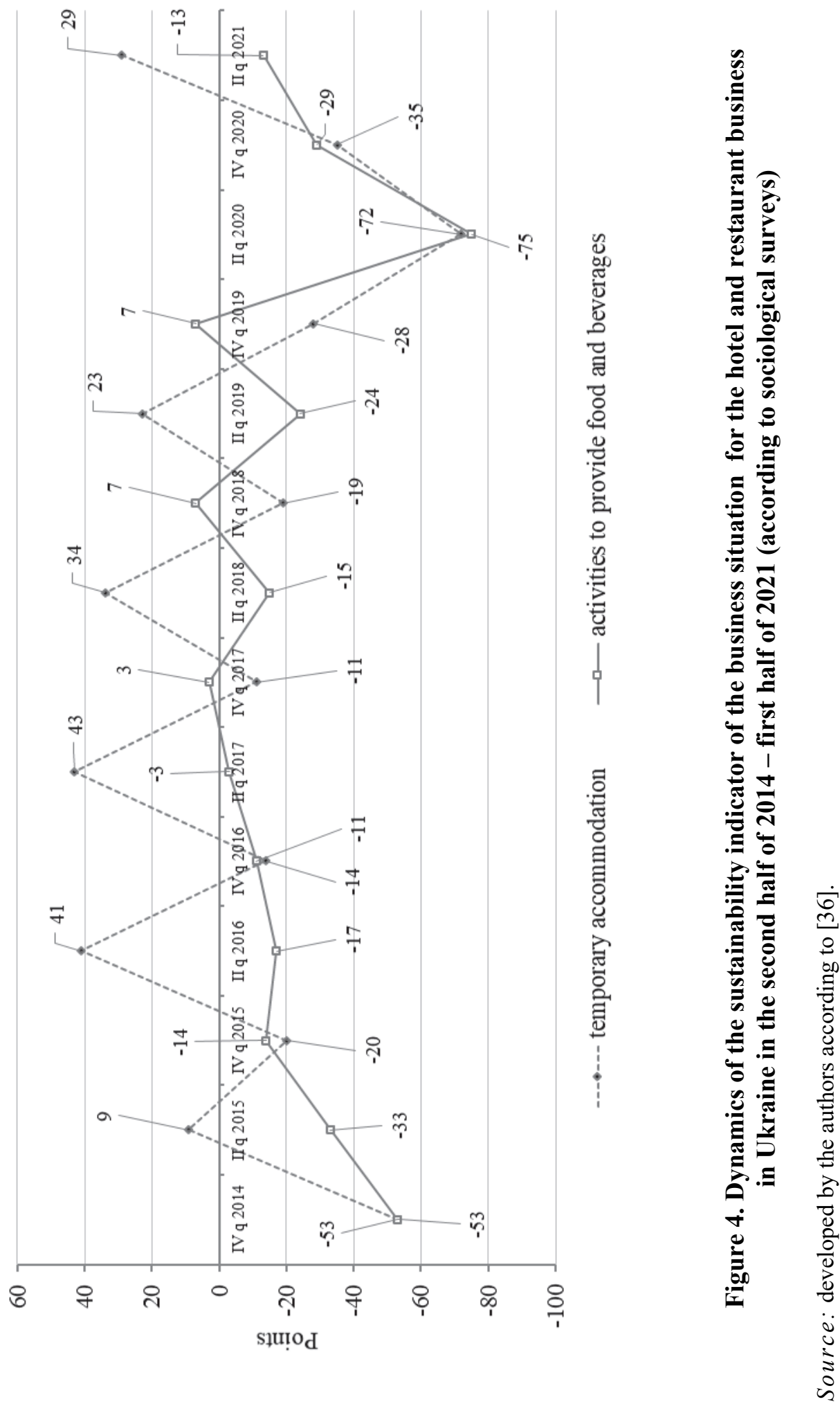

52 ISSN 1727-9313. HERALD OF KNUTE. 2021. NN 6 

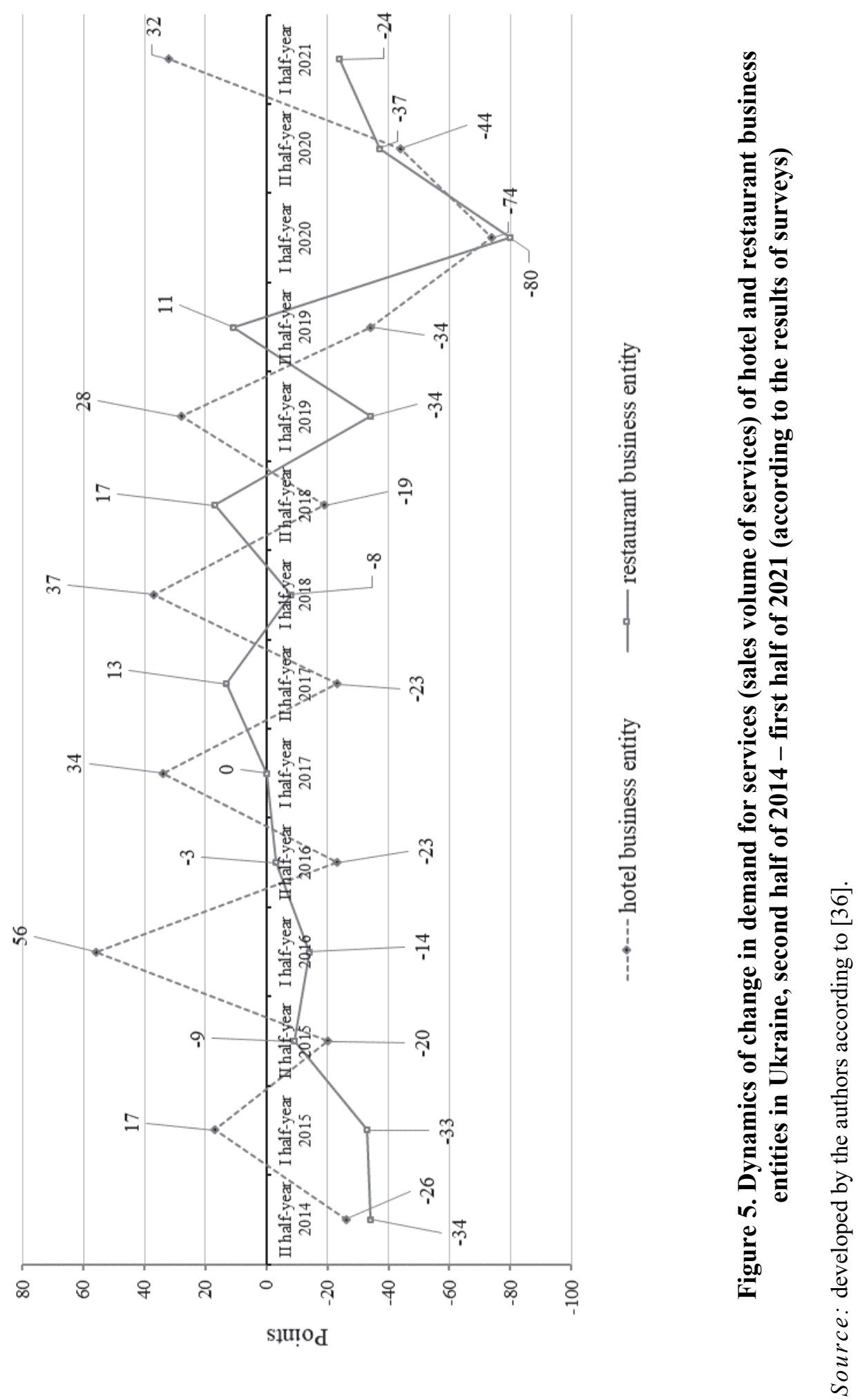

ISSN 1727-9313. HERALD OF KNUTE. 2021. No 6 
Therefore, we propose for practical testing a binary reference model of economic security management, which forms two levels of compliance strategizing (Figure 6).

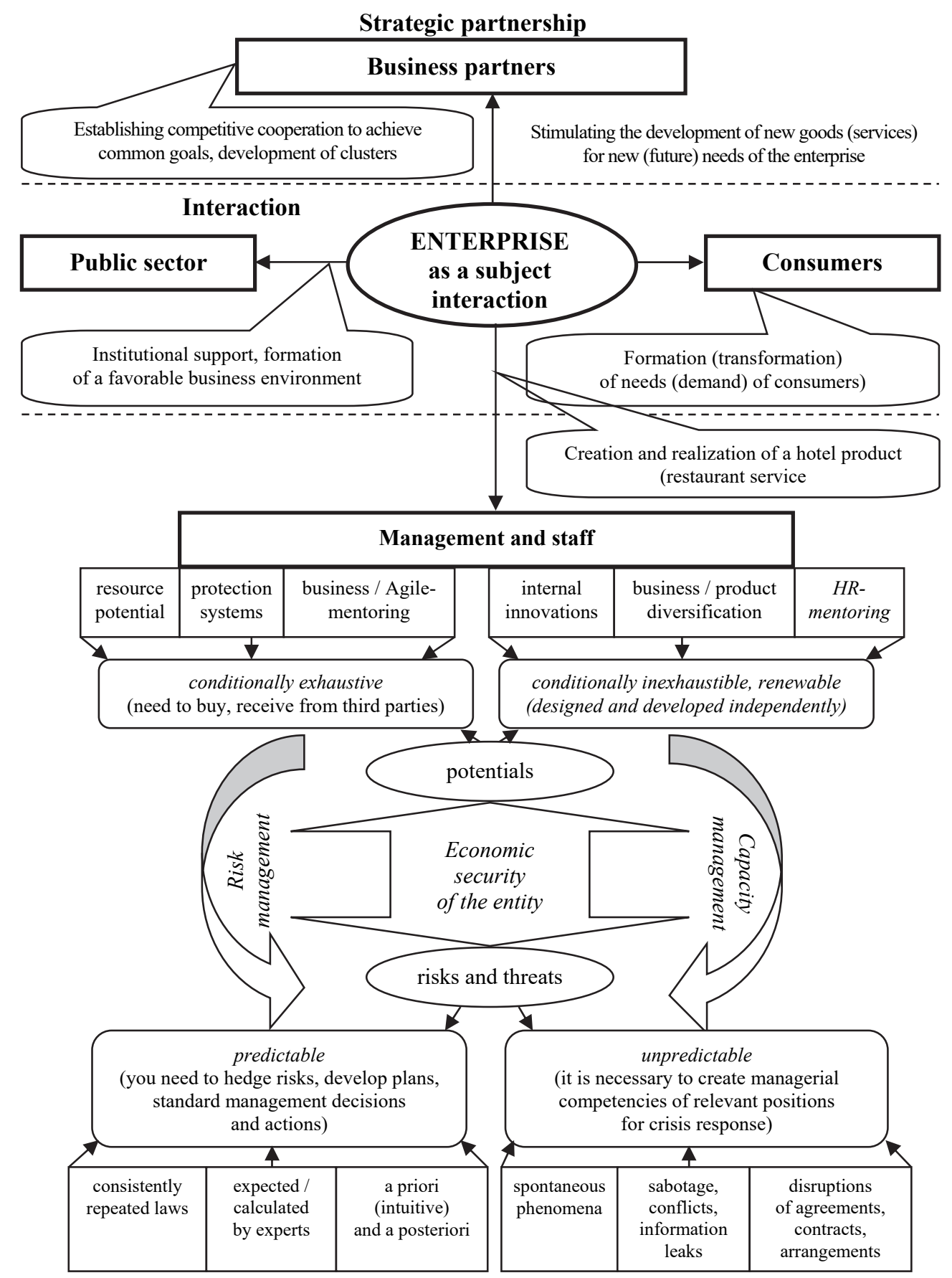

Figure 6. Binary reference model of economic security management of the hospitality entity

Source: developed by the authors. 
The external level includes external participants that form the environment of the hotel business entity (partners, government, consumers) and require mechanisms of cooperation on the basis of strategic partnership. The internal level reveals the content of the management activities of HRBE, contains the mechanisms of formation of management influences and a set of tasks for economic security management, is implemented through the functions and processes of compliance based on the reference model.

The reference model (see Figure 6) allows us to consider economic security management from the standpoint of structural-systemic, process and situational approaches as a trajectory of economic entities interaction based on the transformation of development parameters and through the reflection of business processes.

To implement the binary reference model of economic security management, it is advisable to follow the principles of the situational approach by applying the method of paired molecular docking - defining the architectonics of economic security landmarks (immanent components, molecules): potentials and risks with regard to others. The main purpose of docking is to obtain optimal (according to the established criteria) spatial structures [39], namely, the result is a molecular modeling of the economic security management system as a purposeful structure modification of immanent elements in dynamics to establish "structure-property" dependencies.

In our study, the application of this methodology is due to the need to study the internal potential and resources of the business entity and security elements management ("molecules") - potentials and risks, threats to opportunities, modification of management influences on objects under new environmental conditions. When building a model of economic security compliance, it is important to be guided by the situation: strategic guidelines are fixed as positive (potentials) and negative (risks and threats) elements, and their characteristics are modified around them, forming a comprehensive model of economic security management. The proposed model best reflects the theoretical essence of economic security of the HE and its ability to function effectively in an unstable economic environment.

Thus, compliance-strategy of economic security allows SG to focus on the most important objects of management, which are modified to take into account changing environmental conditions, promising digital innovations and consumers behavior, partners, investors, the public sector.

Thus, the compliance strategizing of economic security allows the HE to focus on the most important management objects that are modified taking into account changing environmental conditions, promising digital innovations and consumers behavior, partners, investors, and the public sector.

Conclusion. The conceptualization of compliance-strateging of economic security of HE in the conditions of digitalization is especially actualized in difficult conditions of instability and uncertainty of external environment increasing owing to influence of epidemiological crisis. Compliance-strategizing of economic security is considered from the standpoint of transformation of the HE management system to ensure risk resilience in an 
unfavorable economic environment by complying with legal and corporate conditions and rules of doing business, opportunities to form mutually beneficial strategic relationships with partners and consumers, balancing internal business processes.

Processing of theoretical aspects of compliance, strateging and economic security makes it possible to model the management system of economic security of the hospitality entity on important internal objects of managerial influences, taking into account strategic guidelines.

Economic and epidemiological crises, which formed external risks associated with business closures, business reorganizations or business process reengineering, have provoked a reset of strategic behavior, the development actualization and implementation of economic security management policies.

The instability and uncertainty of the business environment encourage hospitality market participants to seek unique strategies that form the outposts of economic security.

New challenges of economic realities require modernization of economic security, which is a complementary model for diagnosing the entity environment and its management system, taking into account external aspects - relationship management with partners, consumers, business owners and other stakeholders to protect interests based on capacity management, risks and threats in operational activities and strategic perspective, taking into account digital trends and tendencies.

The binary reference model of HE economic security management allowed to form strategic guidelines of economic security management through compliance-strategizing, which are subject to compliance and require additional professional competencies of managers.

Compliance-based economic security strategizing involves the implementation of a certain configuration of managerial influences on external and internal objects of economic HRBE (security elements ("molecules") potential, risks, threats to opportunities), which is the key to successful crisis management.

Thus, compliance-strategizing is an effective concept of economic security management, which takes into account the opportunities and prospects of economic development, forms an effective mechanism for confronting risks and threats, radical digital transformations. Deepening of diagnostics level of hospitality entities economic security and concept development of change management as a direction of anti-crisis compliance strategy in a pandemic plateau and digital relations are promising for future research .

\section{REFERENCES}

1. Vovk, O., Koval'chuk, A., \& Andrij, P. (2020). Formuvannja komplajenspidhodu do upravlinnja pidpryjemstvom [Formation of a compliance approach to enterprise management]. Tendenze attuali della moderna ricerca scientifica Band 1. DOI: 10.36074/05.06.2020.v1.36 [in Ukrainian]. 
2. Valijev, V. H. (2015). Komplaens-funkcija v suchasnyh pidpryjemstvah prydorozhn'ogo servisu, jak odyn $\mathrm{z}$ efektyvnyh metodiv upravlinnja ryzykamy [Compliance function in modern roadside service enterprises as one of the effective methods of risk management]. Suchasni problemy nauky ta osvity Modern problems of science and education, 2. Part. 2. Retrieved from https://www.scienceeducation.ru/ru/article/view?id=21490 [in Ukrainian].

3. Moskalenko, N. V. (2018). Teoretychni aspekty zaprovadzhennja komplajenskontrolju v Ukrai'ni [Theoretical aspects of the introduction of compliance control in Ukraine]. Ekonomichnyj visnyk - Economic Bulletin, 2, 106-112. Serija: finansy, oblik, opodatkuvannja. DOI: 10.33244/2617-5932.2.2018.106-112 [in Ukrainian].

4. Baker, Tilly, Ceres, Deloitte, \& Spencer, Stuart (2018). Governance Outlook. Projections on Emerging Board Matters. National Association of Corporate Directors, 52 [in English].

5. Bauer, V. P., \& Jer'omin, V. V. (2020). Komplajens-strateguvannja jak instytut reguljuvannja social'no-ekonomichnoi' i nacional'noi' bezpeky: dosvid SShA 「Compliance strategizing as an institution of regulation of socio-economic and national security: the experience of the United States]. Ekonomichna bezpekaEconomic security. Vol. 3, (pp.285-296). DOI:10.18334 / ecsec.3.3.110596 [in Ukrainian].

6. Kasych, A. O. (2020). Strateguvannja rozvytku nacional'noi' ekonomiky jak doktryna bezpekovoi' polityky krai'ny [Strategizing of the national economy development as a doctrine of the country's security policy]. Ekonomichnyj zhurnal Odes'kogo politehnichnogo universytetu - Economic journal Odessa polytechnic university, 3 (13), 13-22. Retrieved from https://economics.opu.ua/ejopu/ 2019/No3/13.pdf. DOI: 10.15276/EJ.03.2020.2. DOI: 10.5281/zenodo.4434920 [in Ukrainian].

7. Kuhars'ka, N. A. (2014). Strateguvannja social'no-ekonomichnogo rozvytku regionu jak novyj pidhid do rozrobky i realizacii' strategij regional'nogo rozvytku [Strategizing of the socio-economic development of the region as a new approach to the development and implementation of regional development strategies]. Social'no-ekonomichni problemy suchasnogo periodu Ukrai'ny Socio-economic problems of the modern period in Ukraine, 3(107), 22-28 [in Ukrainian].

8. Chemerys, V. A. Conceptual principles of innovative development strategizing of rural areas at the regional level. Socio-economic problems of the modern period in Ukraine. ird.gov.ua. Retrieved from http://ird.gov.ua/sep/sep20184(132)/ sep20184(132)_079_ChemerysV,KazmirL.pdf [in Ukrainian].

9. Starbuck, W. H. Strategizing Realistically in Competitive Environments. pages.stern.nyu.edu. Retrieved from http://pages.stern.nyu.edu/ wstarbuc/mob/ strategizg.pdf [in English].

10. Dacjuk, S. Strateguvannja [Strategizing]. www.uis.kiev.ua. Retrieved from http://www.uis.kiev.ua/ _ xyz/6_strategation.htm [in Ukrainian].

11. Dovbnja, S. B., \& Gichova, N. Ju. (2008). Diagnostyka rivnja ekonomichnoi' bezpeky pidpryjemstva [Diagnosis of the economic security level at the enterprise]. Finansy Ukrai'ny - Finance of Ukraine, 4, 88-97 [in Ukrainian].

12. Kalashnikova, E. B. (2019). Risk-Oriented Approach In The System Of Enterprise Economic Security. Cognitive-Crcs; Mar 20. DOI: 10.15405/epsbs.2019.03.67 [in English]. 
13. Mitjakov, S. N. (2019). Metody ocenki riskov jekonomicheskoj bezopasnosti [Methods for assessing the risks of economic security]. Economic security, 2(1), 23-7. DOI: 10.18334 ecsec.2.1.100618 [in Ukrainian].

14. Morozova, E. S. (2020). Formation And Analysis Of The Enterprise Economic Security Balanced Scorecard. European Publisher; Mar 9. DOI: 10.15405/ epsbs.2020.03.29 [in English].

15. Nuray, Rauf R. (2019). Study of the Economic Potential of the Innovative Development of Hotel Enter. Prises in Azerbaijan. Economic Herald of the Donbas. State University Luhansk Taras Shevchenko National University, (4 (58), 61-65. DOI: 10.12958/1817-3772-2019-4(58)-61-65 [in English].

16. Skhiri, O. M. (2018). Managers' Behaviour in Situations of Crisis: The Case of the Hotel Industry in Tunisia. Journal of Hotel and Business Management. OMICS Publishing Group, 07(01). DOI: 10.4172/2169-0286.1000170 [in English].

17. Tarlow, P. E. (2014). Hotel and Motel Security. Tourism Security. Elsevier, 49-78. DOI:10.1016/b978-0-12-411570-5.00003 [in English].

18. Zhu, Y., Sun, Y., Xiang, X. (2020). Economic policy uncertainty and enterprise value: Evidence from Chinese listed enterprises. Economic Systems. Elsevier BV; Dec, 44(4):100831. DOI:10.1016/j.ecosys.2020.100831 [in English].

19. Caldwell, T. (2018). The miners strike - addressing the crypto-currency threat to enterprise networks. Computer Fraud \& Security. Elsevier BV; May, 5, 8-14. DOI: 10.1016/s1361-3723(18)30043-5 [in English].

20. Savel'eva, E. A. (2020). Ekonomichna bezpeka dystancijnogo praci: praktyka cyfrovyh platform ta problemy normatyvno-pravovogo zabezpechennja [Economic security of teleworking: the practice of digital platforms and problems of regulatory support]. Ekonomichna bezpeka - Economic security, 3 (3), 273-284. DOI: 10.18334/ecsec.3.3.110534 [in Ukrainian].

21. Karev, A. V. (2019). Negatyvni efekty cyfrovizacii' [Negative effects of digitalization]. Ekonomichna bezpeka - Economic security, 2 (3), 197-201. DOI: 10.18334/ecsec.2.3.100638 [in Ukrainian].

22. Zeng, W, \& Koutny, M. (2019). Modelling and analysis of corporate efficiency and productivity loss associated with enterprise information security technologies. Journal of Information Security and Applications. Elsevier BV; Dec 49:102385. DOI: 10.1016/j.jisa.2019.102385 [in English].

23. Mukherjee, S. (2019). Enterprise Risk Management for the Implementation of Cloud Security. SSRN Electronic Journal. Elsevier BV. DOI: 10.2139/ssrn.3435908 [in English].

24. Oluwatimi, O., Damiani, M. L., \& Bertino, E. A. (2018). Context-aware system to secure enterprise content: Incorporating reliability specifiers. Computers \& Security. Elsevier BV; Aug;77:162-78. DOI:10.1016/j.cose.2018.04.001 [in English].

25. Bovsh, L., Komarnyc'kyj, I., \& Olijnyk, O. (2021). Nastavnyctvo ta Agile: tochky dotyku $\mathrm{v}$ restorannomu menedzhmenti. Restorannyj ta gotel'nyj konsaltyng [Mentoring and Agile: points of contact in restaurant management. Restaurant and hotel consulting]. Innovacii' - Innovations, 4(1), 39-53. DOI: 10.31866/2616-7468.4.1.2021.234829 [in Ukrainian].

26. Maljuk, L., \& Varypajeva, L. (2019). Teoretychni osnovy bezpeky poslug [Theoretical foundations of service security]. Restoranno-gotel'nyj konsaltyng. Innovacii' - Innovations, 2 (1), 134-143. DOI:10.31866/2616-7468.2.1.2019.170431 [in Ukrainian]. 
27. Sahirova, A. (2021). Zabezpechennja ekonomichnoi' bezpeky v gotel'nomu biznesi za dopomogoju innovacij [Ensuring economic security in the hotel business through innovations]. Pryazovs'kyj ekonomichnyj visnyk - Priazovsky Economic Bulletin, 1 (24). DOI: 10.32840/2522-4263/2021-1-17 [in Ukrainian].

28. Sosnovs'ka, I. M. Ponjattja ta znachennja ekonomichnoi' bezpeky vyrobnychogospodars'koi' dijal'nosti pidpryjemstv [The concept and importance of production and activities economic security of enterprises]. www.economy.nayka.com.ua. Retrieved from http://www.economy.nayka.com.ua/?op=1\&z=4303 [in Ukrainian].

29. Judina, O. (2019). Metodologija vytratnogo pidhodu pry ocinci ekonomichnoi' stabil'nosti pidpryjemstv gotel'no-restorannogo sektoru [Methodology of the cost approach in assessing of the hotel and restaurant sector economic stability]. Ekonomichnyj obsjag - Economic volume, 4, 174-185. DOI: 10.30838/ p.es.2224.040719.174.557 [in Ukrainian].

30. Cambridge dictionary. Retrieved from https://dictionary.cambridge.org/ru/\%D1\% 81\%D0\%BB\%D0\%BE\%D0\%B2\%D0\%B0\%D1\%80D1\%8C/\%D0\%B0\%D0\% BD\%D0\%B3\%D0\%BB\%D0\%B8\%D0\%B9\%D1\%81\%D0\%BA\%D0\%B8\%D $0 \% \mathrm{~B} 9 /$ compliance [in English].

31. Metodychni rekomendacii' shhodo vdoskonalennja korporatyvnogo upravlinnja v bankah Ukrai'ny. Postanova Pravlinnja Nacional’nogo banku Ukrai’ny № 98 vid 28.03.2007r. Methodical recommendations for improving corporate governance in Ukrainian banks. Resolution of the Board of the National Bank of Ukraine № 98 of March 28, 200. Retrieved from https://zakon.rada.gov.ua/ laws/show/v0098500-07\#Text (last access 24.07.2021) [in Ukrainian].

32. What is compliance? Official site of the International Compliance Association. Retrieved from https://www.int-comp.org/careers/your-career-in-compliance/ what-is-compliance (last access: 24.07.2021) [in English].

33. Formagej, O. Pravove reguljuvannja pytan' vidpovidnosti (komplajensu) $\mathrm{v}$ energetychnomu pravi Ukrai'ny [Legal regulation of compliance issues in the energy law of Ukraine]. (Regulatory Compliance). unba.org.ua. Retrieved from https:/unba.org.ua/publications/print/6220-pravove-regulyuvannya-pitan-vidpovidnostikomplaensu-v-energetichnomu-pravi-ukraini-regulatory-compliance.html [in Ukrainian].

34. Ekonomichna bezpeka pidpryjemstv, organizacij, ustanov [Economic security of enterprises, organizations, institutions]. pidru4niki.com. Retrieved from https://pidru4niki.com/1822061151265/ekonomika/osnovi_ekonomichnoyi_bez peki pidpriyemstva [in Ukrainian].

35. Shevchenko, L. S. (2019). Strategichnyj innovacijnyj menedzhment [Strategic innovation management]. Harkiv: Nac. juryd. un-t imeni Jaroslava Mudrogo Retrieved from http://nulau.edu.ua/materials/files/economic_theory/0144/01.pdf [in Ukrainian].

36. Ochikuvannja pidpryjemstv sfery poslug shhodo perspektyv rozvytku i'h dilovoi' aktyvnosti za vydamy ekonomichnoi' dijal'nosti (2015-2021) [Expectations of service enterprises regarding the prospects for the development of their business activity by types of economic activity (2015-2021)]. Retrieved from http://www.ukrstat.gov.ua [in Ukrainian].

37. Majsternja efektyvnogo biznesa. Pryklady provedennja marketyng-analyzu [Effective business workshop. Examples of marketing analysis]. Retrieved from https://master-effect.biz/ https://master-effect.biz [in Ukrainian]. 
38. Pro zatverdzhennja Metodyky rozrahunku indykatoriv dilovyh ochikuvan' zgidno z vymogamy rozshyrenogo Special'nogo standartu poshyrennja danyh Mizhnarodnogo valjutnogo fondu. Nakaz Derzhstatu vid 30.12.2014 № 411 (zi zmin.) [On approval of the Methodology for calculating indicators of business expectations in accordance with the requirements of the extended Special Standard for Dissemination of Data of the International Monetary Fund. Order of the State Statistics Committee of 30.12.2014 № 411 (as amended)]. www.ukrstat.gov.ua. Retrieved from http://www.ukrstat.gov.ua/metod_polog/ metod doc/2014/411/411 2014.htm [in Ukrainian].

39. Meng, E. C., Shoichet, B. K., \& Kuntz, I. D. (2004). Automated docking with grid-based energy evaluation. Journal of Computational Chemistry, 13 (4), 505-524. DOI: 10.1002/jcc.540130412[in English].

The article submitted to editor's office on 14.09.2021.

Бови Л., Босовська М., Охріменко А. Комплаєнс-стратегування економічної безпеки бізнесу в умовах цифровізації.

Постановка проблеми. Тривала криза вітчизняної економіки, поглиблена пандемією, спричинила економічну депресію, щзо негативно позначається на фінансових результатах суб'єктів господарювання. Нестабільні та невизначені умови бізнессередовища потребують створення економічними суб'єктами стратегічних форпостів, які орієнтуються на розвиток діяльності відповідно до певних норм, процедур, правил та стандартів. Тому актуальним завданням є концептуалізація теоретичних основ комплаєнс-стратегування в умовах кризи для забезпечення економічної безпеки суб 'єктів, зокрема у сфері гостинності.

Метою статті $\epsilon$ операціоналізація змісту економічної безпеки суб'єктів гостинності та формування конџептуальної моделі реалізації комплаєнс-стратегування як иілісного багаторівневого поліоб'єктного механізму в умовах ичифровізації.

матеріали та методи. Дослідження сутності економічної безпеки бізнесу та ї̈ складових здійснювалось із застосуванням загальнонаукових методів: узагальнення, абстрагування та аналізу, щзо забезпечило обтрунтування теоретичних аспектів та аргументацію комплементарної моделі економічної безпеки суб'єкта гостинності. Інформаційною базою дослідження стали наукові праці у сфері комплаєнсу, стратегічного управління, економічної безпеки; онлайн-аналітика та офіційні статистичні джерела.

Результати дослідження. Теоретичний аналіз наукових джерел дав змогу сформулювати операційні дефініції й функції комплаєнсу, які є маркерами стратегування. Здійснено декомпозицію комплаєнс-стратегування системи економічної безпеки, щуо складає діагностичний базис суб'єкта гостинності. За елементами економічного потенціалу охарактеризовано політику економічної безпеки та запропоновано концептуальну модель. Надано методичні та практичні рекомендаиї̈ щчодо впровадження бінарної референтної моделі управління економічною безпекою суб'єктів гостинності.

Результати дослідження свідчать про необхідність системного та безперервного управління економічною безпекою, а запропонована методологія спрощує розуміння цуього процесу до конкретних иілей і дій.

Висновки. В умовах повторюваних криз та ескалаиії пандемії комплаєнс-стратегування економічної безпеки є важливим інструментом прогнозування. Дослідження охоплює науково обтрунтовані результати, які комплексно вирішують важливу теоретико-прикладну проблему ефективного управління економічною безпекою суб' сктів гостинності.

Ключові слова: комплаєнс, стратегування, економічна безпека, комплаєнсризики, модель економічної безпеки, цифровізація, цифрові технології, суб'єкт гостинності. 